\title{
PEMAHAMAN UNDANG-UNDANG NOMOR 14 TAHUN 2008 TENTANG KETERBUKAAN INFORMASI PUBLIK
}

\author{
Astim Riyanto ${ }^{1}$
}

\begin{abstract}
Law Number 14 Year 2008 on Public Disclosure of Information expressed information is fundamental requirement each and everyone for personal expansion and its the social environment and is essential part for national resilience. Rights obtains information is human right and disclosure of information of public is one of important characteristic of democratic state respecting popular sovereignty to realize the management of better state disclosure of information of public is supporting facilities for in optimal of public observation to the management of other state and public body and all thing causing at public importance.
\end{abstract}

Kata kunci: Informasi, informasi publik, keterbukaan informasi publik.

\begin{abstract}
Abstrak
Undang-Undang Nomor 14 Tahun 2008 tentang Keterbukaan Informasi Publik menyatakan informasi merupakan kebutuhan pokok setiap orang bagi pengembangan pribadi dan lingkungan sosialnya serta merupakan bagian penting bagi ketahanan nasional. Hak memperoleh informasi merupakan hak asasi manusia dan keterbukaan informasi publik merupakan salah satu ciri penting negara demokratis yang menjunjung tinggi kedaulatan rakyat untuk mewujudkan penyelenggaraan negara yang lebih baik. Keterbukaan informasi publik merupakan sarana dalam mengoptimalkan pengawasan publik terhadap penyelenggaraan negara dan badan publik lainnya dan segala sesuatu yang berakibat pada kepentingan publik.
\end{abstract}

Kata kunci: Informasi, informasi publik, keterbukaan informasi publik.

\section{Pendahuluan}

Substansi (materi muatan) Undang-Undang No. 14 Tahun 2008 tentang Keterbukaan Informasi Publik sebagaimana bisa dilihat dalam "Mengingat" dari Undang-Undang tersebut didasarkan pada dasar hukum Pasal 28F dan Pasal 28J Perubahan Kedua Undang-Undang Dasar Negara Republik Indonesia Tahun 1945 (Perubahan Kedua UUD NRI 1945) tanggal 18 Agustus 2000. Pasal 28F Perubahan Kedua UUD NRI 1945 tahun 2000, berbunyi:

\footnotetext{
${ }^{1}$ Penulis adalah Staf Pengajar
} 
Setiap orang berhak untuk berkomunikasi dan memperoleh informasi untuk mengembangkan pribadi dan lingkungan sosialnya serta berhak untuk mencari, memperoleh, memiliki, menyimpan, mengolah, dan menyampaikan informasi dengan menggunakan segala jenis saluran yang tersedia.

Sementara itu, Pasal 28J Perubahan Kedua UUD NRI 1945 tahun 2000, berbunyi:

Setiap orang wajib menghormati hak asasi manusia orang lain dalam tertib kehidupan bermasyarakat, berbangsa, dan bernegara.

Sebelum Perubahan Kedua UUD NRI 1945 tanggal 18 Agustus 2000, pada tanggal 23 September 1999 telah diundangkan Undang-Undang Republik Indonesia Nomor 39 Tahun 1999 tanggal 23 September 1999 tentang Hak Asasi Manusia. Konsiderans a Undang-Undang Nomor 39 Tahun 1999, menyatakan: "a. bahwa manusia sebagai makhluk ciptaan Tuhan Yang Maha Esa yang mengemban tugas mengelola dan memelihara alam semesta dengan penuh ketakwaan dan penuh tanggung jawab untuk kesejahteraan umat manusia oleh pencipta-Nya dianugerahi hak asasi untuk menjamin keberadaan harkat dan martabat kemuliaan dirinya serta kehormatan lingkungannya".

Konsiderans b Undang-Undang Nomor 39 Tahun 1999, menyatakan: "b. bahwa hak asasi manusia merupakan hak dasar yang secara kodrati melekat pada diri manusia, bersifat universal dan langgeng, karena itu harus dilindungi, dihormati, dipertahankan, dan tidak boleh diabaikan, dikurangi, atau dirampas oleh siapa pun".

Konsiderans c Undang-Undang Nomor 39 Tahun 1999, menyatakan: "c. bahwa selain hak asasi, manusia juga mempunyai kewajiban dasar antara manusia yang satu terhadap yang lain dan terhadap masyarakat secara keseluruhan dalam kehidupan bermasyarakat, berbangsa, dan bernegara".

Konsiderans d Undang-Undang Nomor 39 Tahun 1999, menyatakan: "d. bahwa bangsa Indonesia sebagai anggota Perserikatan Bangsa-Bangsa mengemban tanggung jawab moral dan hukum untuk menjunjung tinggi dan melaksanakan Deklarasi Universal tentang Hak Asasi Manusia yang ditetapkan oleh Perserikatan Bangsa-Bangsa, serta berbagai instrumen internasional lainnya mengenai hak asasi manusia yang telah diterima oleh negara".

Berkenaan dengan batasan hak asasi manusia, Pasal 1 angka 1 UndangUndang Nomor 39 Tahun 1999, merumuskan: "Hak asasi manusia adalah seperangkat hak yang melekat pada hakikat dan keberadaan manusia sebagai makhluk Tuhan Yang Maha Esa dan merupakan anugerah-Nya yang wajib dihormati, dijunjung tinggi dan dilindungi oleh negara, hukum, Pemerintah, dan setiap orang demi kehormatan serta perlindungan harkat dan martabat manusia".

Di sisi lain Pasal 1 angka 2 Undang-Undang Nomor 39 Tahun 1999. mengajukan batasan kewajiban dasar manusia: "Kewajiban dasar manusia 
adalah seperangkat kewajiban yang apabila tidak dilaksanakan, tidak memungkinkan terlaksana dan tegaknya hak asasi manusia".

Berbicara mengenai hak asasi manusia bertalian dengan tindakan diskriminasi, Pasal 1 angka 3 Undang-Undang Nomor 39 Tahun 1999 merumuskan:

Diskriminasi adalah setiap pembatasan, pelecehan, atau pengucilan yang langsung ataupun tak langsung didasarkan pada pembedaan manusia atas dasar agama, suku, ras, etnik, kelompok, golongan, status sosial, status ekonomi, jenis kelamin, bahasa, keyakinan politik, yang berakibat pengurangan, penyimpangan, atau penghapusan pengakuan, pelaksanaan atau penggunaan hak asasi manusia dan kebebasan dasar dalam kehidupan, baik individual maupun kolektif, dalam bidang politik, ekonomi, hukum, sosial, budaya, dan aspek kehidupan lainnya.

\section{Pengertian Keterbukaan Informasi Publik}

Konsiderans a Undang-Undang Nomor 14 Tahun 2008 tanggal 30 April 2008 tentang Keterbukaan Informasi Politik, menyatakan: "a. bahwa informasi merupakan kebutuhan pokok setiap orang bagi pengembangan pribadi dan lingkungan sosialnya serta merupakan bagian penting bagi ketahanan nasional". Konsiderans b Undang-Undang Nomor 14 Tahun 2008, menyatakan: "b. bahwa hak memperoleh informasi merupakan hak asasi manusia dan keterbukaan informasi publik merupakan salah satu ciri penting negara demokratis yang menjunjung tinggi kedaulatan rakyat untuk mewujudkan penyelenggaraan negara yang baik". Konsiderans c UndangUndang Nomor 14 Tahun 2008, menyatakan: "c. bahwa keterbukaan informasi publik merupakan sarana dalam mengoptimalkan pengawasan publik terhadap penyelenggaraan negara dan Badan Publik lainnya dan segala sesuatu yang berakibat pada kepentingan publik". Konsideran d Undang-Undang Nomor 14 Tahun 2008, menyatakan: "d. bahwa pengelolaan informasi publik merupakan salah satu upaya untuk mengembangkan masyarakat informasi”.

Apa yang dimaksud dengan informasi, Pasal 1 angka 1 Undang-Undang Nomor 14 Tahun 2008, merumuskan: "Informasi adalah keterangan, pernyataan, gagasan, dan tanda-tanda yang mengandung nilai, makna, dan pesan, baik data, fakta maupun penjelasannya yang dapat dilihat, didengar, dan dibaca yang disajikan dalam berbagai kemasan dan format sesuai dengan perkembangan teknologi informasi dan komunikasi secara elektronik ataupun nonelektronik".

Selanjutnya, yang dimaksud dengan informasi publik, menurut Pasal 1 angka 2 Undang-Undang Nomor 14 Tahun 2008, yaitu: "Informasi Publik adalah informasi yang dihasilkan, disimpan, dikelola, dikirim, dan/atau diterima oleh suatu badan publik yang berkaitan dengan penyelenggara dan penyelenggaraan negara dan/atau penyelenggara dan penyelenggaraan badan 
publik lainnya yang sesuai dengan undang-undang ini serta informasi lain yang berkaitan dengan kepentingan publik".

\section{Asas dan Tujuan Keterbukaan Informasi Publik}

\section{Asas Kerterbukaan Informasi Publik}

Pasal 2 ayat (1) Undang-Undang Nomor 14 Tahun 2008, menentukan: "Setiap Informasi Publik bersifat terbuka dan dapat diakses oleh setiap Pengguna Informasi Publik".

Pasal 2 ayat (2) Undang-Undang Nomor 14 Tahun 2008, menentukan: "Informasi Publik yang dikecualikan bersifat ketat dan terbatas". Pasal 2 ayat (3) Undang-Undang Nomor 14 Tahun 2008, menentukan: "Setiap Informasi Publik harus dapat diperoleh setiap Pemohon Informasi Publik dengan cepat dan tepat waktu, biaya ringan, dan cara sederhana.

Pasal 2 ayat (4) Undang-Undang Nomor 14 Tahun 2008, menentukan:

Infromasi Publik yang dikecualikan bersifat rahasia sesuai dengan undang-undang, kepatutan, dan kepentingan umum didasarkan pada pengujian tentang konsekuensi yang timbul apabila suatu informasi diberikan kepada masyarakat serta setelah dipertimbangkan dengan saksama bahwa menutup Informasi Publik dapat melindungi kepentingan yang lebih besar daripada membukanya atau sebaliknya.

\section{Tujuan Kerterbukaan Informasi Publik}

Pasal 3 Undang-Undang Nomor 14 Tahun 2008, menentukan Undang-undang ini bertujuan untuk: a. menjamin hak warga negara untuk mengetahui rencana pembuatan kebijakan publik, program kebijakan publik, dan proses pengambilan keputusam publik, serta alasan pengambilan suatu keputusan publik; b. mendorong partisipasi masyarakat dalam proses pengambilan kebijakan publik; c. meningkatkan peran aktif masyarakat dalam pengambilan kebijakan publik dan pengelolaan Badan Publik yang baik; d. mewujudkan penyelenggaraan negara yang baik, yaitu yang transparan, efektif, dan efisien, akuntabel serta dapat dipertanggungjawabkan; e. mengetahui alasan kebijakan publik yang mempengaruhi hajat hidup orang banyak; $f$. mengembangkan ilmu pengetahuan dan mencerdaskan kehidupan bangsa; dan/atau meningkatkan pengelolaan dan pelayanan informasi di lingkungan Badan Publik untuk menghasilkan layanan informasi yang berkualitas. 


\section{Badan Publik}

Pasal 1 angka 3 Undang-Undang Nomor 14 Tahun 2008 juncto (jo) Pasal 1 angka 3 Peraturan Komisi Informasi Nomor 1 Tahun 2010 tentang Standar Layanan Informasi Publik, merumuskan: "Badan Publik adalah lembaga eksekutif, legislatif, yudikatif, dan badan lain yang fungsi dan tugas pokoknya berkaitan dengan penyelenggaraan negara, yang sebagian atau seluruh dananya bersumber dari Anggaran Pendapatan dan Belanja Negara/Anggaran Pendapatan dan Belanja Daerah, atau organisasi nonpemerintah sepanjang sebagian atau seluruh dananya bersumber dari Anggaran Pendapatan dan Belanja Negara dan/atau Anggaran Pendapatan dan Belanja Daerah, sumbangan masyarakat, dan/atau luar negeri”.

Lampiran I Peraturan Komisi Informasi Nomor 1 Tahun 2010 tentang Standar Layanan Informasi Publik menyebutkan Badan Publik:

1. Lembaga Eksekutif meliputi: a. Kementerian Negara (berdasarkan Peraturan Presiden Nomor 47 Tahun 2009) terdiri atas: 1) Kementerian Koordinator (Bidang Politik, Hukum, dan Keamanan; Bidang Perekonomian, serta Kesejahteraan Rakyat) dan 2) Kementerian (Sekretariat Negara, Dalam Negeri, Luar Negeri, Pertahanan, Hukum dan Hak Asasi Manusia, Keuangan, Energi dan Sumber Daya Mineral, Perindustrian, Perdagangan, Pertanian, Kehutanan, Perhubungan, Kelautan dan Perikanan, Tenaga Kerja dan Transmigrasi, Pekerjaan Umum, Kesehatan, Pendidikan Nasional, Sosial, Agama, Kebudayaan dan Pariwisata, Komunikasi dan Informatika, Riset dan Teknologi, Koperasi dan Usaha Kecil dan Menengah, Lingkungan Hidup, Pemberdayaan Perempuan dan Perlindungan Anak, Pendayagunaan Aparatur Negara dan Reformasi Birokrasi, Pembangunan Daerah Tertinggal, Perencanaan Pembangunan Nasional, Badan Usaha Milik Negara, Perumahan Rakyat, dan Pemuda dan Olahraga); b. Pemerintahan Daerah (Pemerintahan Provinsi, DPRD Provinsi, Pemerintah Daerah Kabupaten/Kota, dan DPRD Kabupaten/Kota); 3) Pemerintah Desa/Kelurahan; c. Lembaga Pemerintah Non Kementerian (Arsip Nasional Republik Indonesia/ANRI, Badan Intelijen Negara/BIN, Badan Kepegawaian Negara/BKN, Badan Koordinasi Keluarga Berencana Nasional/BKKBN, Badan Koordinasi Penanaman Modal/BKPM, Badan Koordinasi Survei dan Pemetaan Nasional/Bakorsurtanal, Badan Meteorologi dan Geofisika/BMG, Badan Pengawas Obat dan Makanan/BPOM, Badan Pengawasan Perdagangan Berjangka Komoditi/BPPBK, Badan Pengawas Tenaga Nuklir/ BAPETEN, Badan Pengawasan Keuangan dan Pembangunan/BPKP, Badan Pengembangan Kebudayaan dan Pariwisata, Badan Pengkajian dan Penerapan Teknologi/BPPT, Badan Pertanahan Nasional/BPN, Badan Pusat Statistik/BPS, Badan Standardisasi Nasional/BSN, Badan Tenaga Nuklir Nasional/BATAM, Badan Urusan Logistik/BULOG, Lembaga Administrasi Negara/LAN, Lembaga Ilmu Pengetahuan Indonesia/LIPI, Lembaga Penerbangan dan Antariksa Nasional/LAPAN, dan Perpustakaan Nasional Republik Indonesia; 5) Kepolisian Negara Republik Indonesia/ 
POLRI (Markas Besar Kepolisian RI, Kepolisian Daerah, Kepolisian Resort, dan Kepolisian Sektor; 6) Kejaksaan Republik Indonesia (Kejaksaan Agung, Kejaksaan Tinggi, dan Kejaksaan Negeri).

2. Lembaga Legislatif (berdasarkan UUD NRI 1945 dan UU Nomor 27 Tahun 2009 tentang MPR, DPR, DPD, dan DPRD) terdiri atas: Majelis Permusyawaratan Rakyat Republik Indonesia (MPR RI), Dewan Perwakilan Rakyat Republik Indonesia (DPR RI), dan Dewan Perwakilan Daerah Republik Indonesia (DPD RI).

3. Lembaga Yudikatif terdiri atas: a. Mahkamah Agung Republik Indonesia: 1) Peradilan Umum: Pengadilan Negeri, Pengadilan Tinggi, Pengadilan Khusus di bawahnya: Pengadilan Niaga, Pengadilan HAM, Pengadilan Hubungan Industrial, Pengadilan Perikanan, dan Pengadilan Tindak Pidana Korupsi; 2) Peradilan Agama: Pengadilan Agama dan Pengadilan Tinggi Agama; 3) Peradilan Militer: Pengadilan Militer, Pengadilan Militer Tinggi, Pengadilan Militer Utama, dan Pengadilan Militer Pertempuran; 4) Peradilan Tata Usaha Negara: Pengadilan Tata Usaha Negara, Pengadilan Tinggi Tata Usaha Negara, Pengadilan Khusus di bawahnya antara lain: Pengadilan Pajak; b. Mahkamah Konstitusi RI.

4. Badan Lain yang Fungsi dan Tugas Pokoknya Berkaitan Dengan Penyelenggaraan Negara yang Sebagian atau Seluruh Dananya Bersumber dari APBN/APBD terdiri atas:

a. Komisi: 1) Komisi Yudisial (Pasal 24B UUD NRI 1945 dan UU Nomor 22 Tahun 2004), 2) Komisi Pemilihan Umum (Pasal 22E UUD NRI 1945 dan UU Nomor 22 Tahun 2007), 3) Komisi Nasional Hak Asasi Manusia (Keppres Nomor 48 Tahun 2001 dan UU Nomor 39 Tahun 1999), 4) Komisi Pengawas Persaingan Usaha (UU Nomor 5 Tahun 1999), 5) Komisi Penyiaran Indonesia (UU Nomor 32 tahun 2002), 6) Komisi Pemberantasan Tindak Pidana Korupsi (UU Nomor 30 Tahun 2002), 7) Komisi Perlindungan Anak (UU Nomor 23 Tahun 2002), 8) Komisi Informasi (UU Nomor 14 Tahun 2008), 9) Komisi Hukum Nasional (Keppres Nomor 15 Tahun 2000), 10) Komisi Kepolisian (UU Nomor 2 Tahun 2002), 11) Komisi Kejaksaan (UU No. 16 Tahun 2004 dan Perpres Nomor 18 Tahun 2005), 12) Komisi Nasional Anti Kekerasan Terhadap Perempuan (Keppres Nomor 181 Tahun 1998 dan Prepres Nomor 65 Tahun 2005).

b. Dewan: 1) Dewan Pers (UU Nomor 40 Tahun 1999), 2) Dewan Pendidikan (UU Nomor 20 Tahun 2003), 3) Dewan Pembina Industri Strategis (Keppres Nomor 40 Tahun 1999), 4) Dewan Riset Nasional (Keppres Nomor 94 Tahun 1999), 5) Dewan Buku Nasional (Keppres Nomor 110 Tahun 1999), 6) Dewan Maritim Indonesia (Keppres Nomor 161 tahun 1999), 7) Dewan Ekonomi Nasional (Keppres Nomor 144 Tahun 1999), 8) Dewan Pengembangan Usaha Nasional (Keppres Nomor 165 Tahun 1999), 9) Dewan Gula Nasional (Keppres Nomor 23 Tahun 2003), 10) Dewan Ketahanan Pangan (Keppres Nomor 132 Tahun 2001), 11) Dewan Pengembangan Kawasan Timur Indonesia (Keppres Nomor 44 Tahun 2002), 12) Dewan Pertimbangan Otonomi 
Daerah (Keppres Nomor 151 Tahun 2000), 13) Dewan Pertahanan Nasional (UU Nomor 3 Tahun 2003), 14) Dewan Penerbangan dan Antariksa Nasional (Keppres Nomor 132 Tahun 1998).

c. Komite: 1) Komite Nasional Keselamatan Transportasi (UU Nomor 41 Tahun 1999 dan Keppres Nomor 105 Tahun 1999), 2) Komite Antar Departemen Bidang Kehutanan (Keppres Nomor 80 Tahun 2000), 3) Komite Akreditasi Nasional (Keppres Nomor 78 Tahun 2001), 4) Komite Penilaian Independen (Keppres Nomor 99 Tahun 2009), 5) Komite Olahraga Nasional Indonesia (Keppres Nomor 72 Tahun 2001), 6) Komite Kebijakan Sektor Keuangan (Keppres Nomor 89 Tahun 1999), 7) Komite Aksi Nasional Penghapusan Bentuk-Bentuk Pekerjaan Terburuk untuk Anak (Keppres Nomor 12 Tahun 2000).

d. Badan: 1) Badan Pengawas Pemilu (UU Nomor 22 Tahun 2007), 2) Badan Narkotika Nasional (Keppres Nomor 17 Tahun 2002), 3) Badan Nasional Penanggulangan Bencana (UU Nomor 24 Tahun 2007), 4) Badan Pengembangan Kawasan Ekonomi Terpadu (Keppres Nomor 150 Tahun 2002), 5) Badan Koordinasi Pengembangan TKI (Keppres Nomor 29 Tahun 1999), 6) Badan Pengelola Gelora Bung Karno (Keppres Nomor 72 Tahun 1999), 7) Badan Pengelola Kawasan Kemayoran (Keppres Nomor 73 Tahun 1999), 8) Badan Rekonstruksi dan Rekonsiliasi Provinsi NAD dan Kep. Nias Sumatera Utara (Perpu Nomor 2 Tahun 2005), 9) Badan Nasional Sertifikasi Profesi (PP Nomor 23 Tahun 2004), 10) Badan Pengatur Jalan Tol (PP Nomor 15 Tahun 2005), 11) Badan Pendukung Pengembangan Sistem Penyediaan Air Minum (PP Nomor 16 Tahun 2005), 12) Badan Pengelola Pusat Penelitian Ilmu Pengetahuan dan Tenologi (Keppres Nomor 43 Tahun 1976), 13) Badan Pengembangan Kehidupan Bernegara (Keppres Nomor 85 Tahun 1999).

e. Lembaga: 1) Lembaga Perlindungan Saksi dan Korban (UU Nomor 13 Tahun 2006), 2) Lembaga Koordinasi dan Pengendalian Peningkatan Kesejehateraan Sosial Penyandang Cacat (Keppres Nomor 8 Tahun 1999), 3) Lembaga Sensor Film (PP Nomor 8 tahun 1994).

f. Lembaga Pendidikan Negeri: 1) Seluruh Lembaga Pendidikan Negeri, mulai dari tingkat Taman Kanak-Kanak, Sekolah Dasar, Sekolah Menengah Pertama, Sekolah Menengah Atas, dan Perguruan Tinggi.

g. Badan Hukum Milik Negara: 1) Universitas Indonesia (PP Nomor 152 Tahun 2000), 2) Universitas Gajah Mada (PP Nomor 153 Tahun 2000), 3) Institut Pertanian Bogor (PP Nomor 154 Tahun 2000), 4) Institut Teknologi Bandung (PP Nomor 155 Tahun 2000), 5) Universitas Sumatera Utara (PP Nomor 56 Tahun 2003), 6) Universitas Pendidikan Indonesia (PP Nomor 6 Tahun 2004), 7) Universitas Airlangga (PP Nomor 30 Tahun 2006).

h. Bentuk lain: 1) Pusat Pelaporan dan Analisis Transaksi Keuangan (UU Nomor 25 Tahun 2003 dan Keppres Nomor 81 Tahun 2003), 2) Tim Koordinasi Penanggulangan Kemiskinan (Keppres Nomor 54 Tahun 
2005), 3) Konsil Kedokteran Indonesia (UU Nomor 29 Tahun 2004), 4) Ombudsman Republik Indonesia (UU Nomor 37 Tahun 2008), 5) Satuan Tugas Pemberantasan Mafia Hukum, 6) Unit Kerja Bidang Pengawasan dan Pengendalian Pembangunan, 7) Dewan Pertimbangan Presiden, 8) Peradilan Pajak, 9) Badan Penyelesaian Sengketa Konsumen.

5. Organisasi Non-Pemerintah sesuai dengan Undang-Undang Keterbukaan Informasi Publik: 1) Persatuan berdasarkan keagamaan seperti Nahdlatul Ulama, Muhammadiyah, Persekutuan Gereja Indonesia, Persatuan Umat Khatolik, WALUBI, Parisada Hindu Dharma Indonesia, dan lain-lain; 2) Yayasan seperti Yayasan Lembaga Bantuan Hukum Indonesia, Yayasan RCTI Peduli, Dompet Dhuafa, dan lain-lain; 3) Perkumpulan/Forum seperti Wahana Lingkungan Hidup Indonesia dan lain-lain; 4) Berbagai organisasi dalam masyarakat lainnya sepanjang sebagian atau seluruh dananya bersumber dari APBN/APBD, sumbangan masyarakat, dan/atau luar negeri.

6. Partai Politik di Tingkat Nasional dan Daerah: 1) Partai Hati Nurani Rakyat, 2) Partai Karya Peduli Bangsa, 3) Partai Pengusaha dan Pekerja Indonesia, 4) Partai Peduli Rakyat Nasional, 5) Partai Gerakan Indonesia Raya, 6) Partai Barisan Nasional, 7) Partai Keadilan dan Persatuan Indonesia, 8) Partai Keadilan Sejahtera, 9) Partai Amanat Nasional, 10) Partai Perjuangan Indonesai Baru, 11) Partai Kedaulatan, 12) Partai Persatuan Daerah, 13) Partai Kebangkitan Bangsa, 14) Partai Pemuda Indonesia, 15) Partai Nasional Indonesia Marhaenisme, 16) Partai Demokrasi Pembaharuan, 17) Partai Karya Perjuangan, 18) Partai Matahari Bangsa, 19) Partai Penegak Demokrasi Indonesia, 20) Partai Demokrasi Kebangsaan, 21) Partai Republik Nusantara, 22) Partai Pelopor, 23) Partai Golongan Karya, 24) Partai Persatuan Pembangunan, 25) Partai Damai Sejahtera, 26) Partai Nasional Benteng Kerakyatan Indonesia, 27) Partai Bulan Bintang, 28) Partai Demokrasi Indonesia Perjuangan, 29) Partai Bintang Reformasi, 30) Partai Patriot, 31) Partai Demokrat, 32) Partai Kasih Demokrasi Indonesia, 33) Partai Indonesia Sejahtera, 34) Partai Kebangkitan Nasional Ulama.

7. Badan Usaha Milik Negara/Daerah: 1) Perum Perumnas, 2) Perum Bulog, 3) Perum DAMrI, 4) Perum Jaminan Kredit Indonesia, 5) Perum Jasa Tirta I, 6) Perum Jasa Tirta II, 7) Perum Pegadaian, 8) Perum Percetakan Negara Indonesia, 9) Perum Percetakan Uang RI, 10) Perum Perhutani, 11) PT Adhi Karya Tbk, 12) PT Amarta Karya, 13) PT Angkasa Pura I, 14) PT Angkasa Pura II, 15) PT Angkutan Sungai Danau dan Penyeberangan, 16) PT Antam Tbk, 17) PT Asuransi Ekspor Indonesia, 18) PT Asuransi Jasa Indonesia, 19) PT Asuransi Jasa Raharja, 20) PT Asuransi Jiwasraya, 21) PT Asuransi Kesehatan Indonesia, 22) PT Bahtera Adhiguna, 23) PT Bali Tourism Development Corp, 24) PT Bank Ekspor Indonesia, 25) PT Bank Mandiri, 26) PT Bank Negara Indonesia, 27) PT Bank Rakyat Indonesia Tbk, 28) PT Bank Tabungan Negara, 29) PT Barata Indonesia, 30) PT Bhanda Ghara Reksa, 31) PT Bio Farma, 32) PT Giro 
Klasifikasi Indonesia, 33) PT Boma Bisma Indra, 34) PT Brantas Abipraya, 35) PT Dahana, 36) Danareksa, 37) PT Dirgantara Indonesia, 38) PT Djakarta Llyoyd, 39) PT Dok dan Perkapalan Kodja Bahari, 40) PT Dok dan Perkapalan Surabaya, 41) PT Garam, 42) PT Garuda Indonesia, 43) PT Hotel Indonesia Natour, 44) PT Hutama Karya, 45) PT Indofarma Tbk, 46) PT Indra Karya, 47) PT Inhutani I, 48) PT Inhutani III, 49) PT Inti, 50) PT Jamsostek, 51) PT Jasa Marga, 52) PT Kawasan Berikat Nusantara, 53) PT Kawasan Industri Makassar, 54) PT Kawasan Industri Wijayakusuma, 55) PT Kereta Api Indonesia, 56) PT Kertas Leces, 57) PT Kimia Farma Tbk, 58) PT Kliring Berjangka Indonesia, 59) PT Krakatau Steel, 60) PT LEN Industri, 61) PT Merpati Nusantara Airlines, 62) PT Nindya Karya, 63) PT PAN Multi Finance, 64) PT Pelabuhan Indonesia I, 65) PT Pelabuhan Indonesia II, 66) PT Pelabuhan Indonesia III, 67) PT Pelabuhan Indonesia IV, 68) PT Pelayaran Nasional Indonesia, 69) PT Pembangunan Perumahan, 70) PT Perkebunan Nusantara III, 71) PT Perkebunan Nusantara IV, 72) PT Perkebunan Nusantara IX, 73) PT Perkebunan Nusantara V, 74) PT Perkebunan Nusantara VI, 75) PT Perkebunan Nusantara VII, 76) PT Perkebunan Nusantara VIII, 77) PT Perkebunan Nusantara X, 78) PT Perkebunan Nusantara XI, 79) PT Perkebunan Nusantara XII, 80) PT Perkebunan Nusantara XIII, 81) PT Perkebunan Nusantara XIV, 82) PT Permodalan Nasional Madani, 83) PT Pertamina, 84) PT Pertani, 85) PT Perusahaan Gas Negara Tbk, 86) PT Perusahaan Listrik Negara, 87) PT Perusahaan Pengelola Aset, 88) PT Perusahaan Perdagangan Indonesia, 89) PT PINDAD, 90) PT Pos Indonesia, 91) PT Pupuk Sriwijaya, 92) PT Rajawali Nusantara Indonesia, 93) PT Reasuransi Umum Indonesia, 94) PT Sang Hyang Seri, 95) PT Sarinah, 96) PT Semen Baturaja, 97) PT Semen Gresik, 98) PT Sucofindo, 99) PT Surveyor Indonesia, 100) PT Tambang Batubara Bukit Asam Tbk, 101) PT Taspen, 102) PT Telekomunikasi Indonesia Tbk, 103) PT Timah Tbk, 104) PT TWC Borobudur, Prambanan dan Ratu Boko, 105) PT Waskita Karya, 106) PT Wijaya Karya, 107) Bank Daerah seperti Bank DKI, Bank Sumut, Bank Jabar, Bank Papua, dan Bank daerah lainnya, 108) Perusahaan Daerah Air Minum.

8. Lembaga atau Badan atau Organisasi yang memenuhi kriteria sebagaimana dimaksud dalam Undang-Undang Keterbukaan Informasi Publik, tetapi belum masuk pada Lampiran sebagaimana dimaksud pada ayat (2) tetap dianggap Badan Publik sebagaimana diatur dalam UndangUndang Keterbukaan Informasi Publik.

\section{Hak dan Kewajiban Badan Publik}

\section{Hak Badan Publik}

Pasal 6 ayat (1) Undang-Undang Nomor 14 Tahun 2008, menentukan: "Badan Publik berhak menolak memberikan informasi yang dikecualikan sesuai dengan ketentuan peraturan perundang-undangan". 
Pasal 6 ayat (2) Undang-Undang Nomor 14 Tahun 2008, menentukan: "Badan Publik berhak menolak memberikan Informasi Publik apabila tidak sesuai dengan ketentuan peraturan perundang-undangan". Pasal 6 ayat (3) Undang-Undang Nomor 14 Tahun 2008, menentukan: "Informasi Publik yang tidak dapat diberikan oleh Badan Publik, sebagaimana dimaksud pada ayat (1) adalah: a. informasi yang dapat membahayakan negara; b. informasi yang berkaitan dengan kepentingan perlindungan usaha dari persaingan usaha tidak sehat; c. informasi yang berkaitan dengan hak-hak pribadi; d. infromasi yang berkaitan dengan rahasia jabatan; dan/atau e. Informasi Publik yang diminta belum dikuasai atau didokumentasikan".

\section{Kewajiban Badan Publik}

Pasal 7 ayat (1), ayat (2), ayat (3), ayat (4), dan ayat (5) UndangUndang Nomor 14 Tahun 2008, mengatur: Ayat (1) Badan Publik wajib menyediakan, memberikan dan/atau menerbitkan Informasi Publik, selain informasi yang dikecualikan sesuai dengan ketentuan; Ayat (2) Badan Publik wajib menyediakan Informasi Publik yang akurat, benar, dan tidak menyesatkan; Ayat (3) Untuk melaksanakan kewajiban sebagaimana dimaksud pada ayat (2), Badan Publik harus membangun dan mengembangkan sistem informasi dan dokumentasi untuk mengelola Informasi Publik secara baik dan efisien sehingga dapat diakses dengan mudah; Ayat (4) Badan Publik wajib membuat pertimbangan secara tertulis setiap kebijakan yang diambil untuk memenuhi hak setiap orang atas Informasi Publik; serta Ayat (5) Pertimbangan sebagaimana dimaksud pada ayat (4) antara lain memuat pertimbangan politik, ekonomi, sosial, budaya, dan/atau pertahanan dan keamanan negara.

Pasal 7 ayat (6) Undang-Undang Nomor 14 Tahun 2008, menentukan: "Dalam rangka memenuhi kewajiban sebagaimana dimaksud pada ayat (1) sampai dengan ayat (4) Badan Publik dapat memanfaatkan sarana dan/atau media elektronik dan nonelektronik". Pasal 8 Undang-Undang Nomor 14 Tahun 2008, menentukan: "Kewajiban Badan Publik yang berkaitan dengan kearsipan dan pendokumentasian Informasi Publik dilaksanakan berdasarkan peraturan perundang-undangan".

\section{Hak dan Kewajiban Pemohon dan Pengguna Informasi Publik}

\section{Hak Pemohon Informasi Publik}

Pasal 4 ayat (1) Undang-Undang Nomor 14 Tahun 2008, menentukan: "Setiap orang berhak memperoleh Informasi Publik sesuai dengan ketentuan undang-undang ini". Pasal 4 ayat (2) Undang-Undang Nomor 14 Tahun 2008, menentukan: "Setiap orang berhak: a. melihat dan mengetahui Informasi Publik; b. menghadiri pertemuan publik yang 
terbuka untuk umum untuk memperoleh Informasi Publik; c. mendapatkan salinan Informasi Publik melalui permohonan sesuai dengan undang-undang ini; dan/atau d. menyebarluaskan Informasi Publik sesuai dengan peraturan perundang-undangan". Pasal 4 ayat (3) Undang-Undang Nomor 14 Tahun 2008, menentukan: "Setiap Pemohon Informasi Publik berhak mengajukan permintaan Informasi Publik disertai alasan permintaan tersebut". Pasal 4 ayat (4) Undang-Undang Nomor 14 Tahun 2008, menentukan: "Setiap Pemohon Informasi Publik berhak mengajukan gugatan ke pengadilan apabila dalam memperoleh Informasi Publik mendapat hambatan atau kegagalan sesuai dengan ketentuan undang-undang ini”.

\section{Kewajiban Pengguna Informasi Publik}

Pasal 5 ayat (1) Undang-Undang Nomor 14 Tahun 2008, menentukan: "Pengguna Informasi Publik wajib menggunakan Informasi Publik sesuai dengan ketentuan peraturan perundang-undangan". Pasal 5 ayat (2) Undang-Undang Nomor 14 Tahun 2008, menentukan: "Pengguna Informasi Publik wajib mencantumkan sumber dari mana ia memperoleh Infromasi Publik, baik yang digunakan untuk kepentingan sendiri maupun untuk keperluan publikasi sesuai dengan ketentuan peraturan perundang-undangan".

\section{Informasi yang Wajib Disediakan dan Diumumkan}

\section{Informasi yang Wajib Disediakan dan Diumumkan Secara Berkala}

Pasal 9 ayat (1) Undang-Undang Nomor 14 Tahun 2008, menentukan: "Setiap Badan Publik wajib mengumumkan Informasi Publik secara berkala". Pasal 9 ayat (2) Undang-Undang Nomor 14 Tahun 2008, menentukan: "Informasi Publik sebagaimana dimaksud pada ayat (1) meliputi: a. informasi yang berkaitan dengan Badan Publik; b. informasi mengenai kegiatan dan kinerja Badan Publik terkait; c. informasi mengenai laporan keuangan; dan/atau d. informasi lain yang diatur dalam peraturan perundang-undangan". Pasal 9 ayat (3), ayat (4), ayat (5), dan ayat (6) Undang-Undang Nomor 14 Tahun 2008, mengatur: Kewajiban memberikan dan menyampaikan Informasi Publik dilakukan paling singkat 6 bulan sekali (ayat (3)); Kewajiban menyebarluaskan Informasi Publik disampaikan dengan cara yang mudah dijangkau oleh masyarakat dan dalam bahasa yang mudah dipahami (ayat (4)); Cara-cara ditentukan lebih lanjut oleh Pejabat Pengelola Informasi dan Dokumentasi di Badan Publik terkait (ayat (5)); serta Ketentuan lebih lanjut mengenai kewajiban Badan Publik memberikan dan menyampaikan Informasi Publik secara berkala diatur dengan Petunjuk Teknis Komisi Informasi. 


\section{Informasi yang Wajib Diumumkan secara Serta Merta}

Pasal 10 ayat (1) dan ayat (2) Undang-Undang Nomor 14 Tahun 2008, mengatur: Badan Publik wajib mengumumkan secara serta merta suatu informasi yang dapat mengancam hajat hidup orang banyak dan ketertiban umum (ayat (1)) dan Kewajiban menyebarluaskan Informasi Publik disampaikan dengan cara yang mudah dijangkau oleh masyarakat dan dalam bahasa yang mudah dipahami (ayat (2)).

\section{Informasi yang Wajib Tersedia Setiap Saat}

Pasal 11 ayat (1) Undang-Undang Nomor 14 Tahun 2008, menentukan: Badan Publik wajib menyediakan Informasi Publik setiap saat yang meliputi: a. daftar seluruh Informasi Publik yang berada di bawah penguasaannya, tidak termasuk informasi yang dikecualikan; $b$. hasil keputusan Badan Publik dan pertimbangannya; c. seluurh kebijakan yang ada berikut dokumen pendukungnya; d. rencana kerja proyek termasuk di dalamnya perkiraan pengeluaran tahunan Badan Publik; e. perjanjian Badan Publik dengan pihak ketiga; f. informasi dan kebijakan yang disampaikan Pejabat Publik dalam pertemuan yang terbuka untuk umum; g. prosedur kerja pegawai Badan Publik yang berkaitan dengan pelayanan masyarakat; dan/atau h. laporan mengenai pelayanan akses Informasi Publik sebagaimana diatur dalam undang-undang ini. Pasal 11 ayat (2) Undang-Undang Nomor 14 Tahun 2008, menentukan: Informasi Publik yang telah dinyatakan terbuka bagi masyarakat berdasarkan mekanisme keberatan dan/atau penyelesaian sengketa dinyatakan sebagai Informasi Publik yang dapat diakses oleh Pengguna Informasi Publik. Pasal 11 ayat (3) Undang-Undang Nomor 14 Tahun 2008, menentukan: Ketentuan lebih lanjut mengenai tata cara pelaksanaan kewajiban Badan Publik menyediakan Informasi Publik yang dapat diakses oleh Pengguna Informasi Publik diatur dengan Petunjuk Teknis Komisi Informasi.

Pasal 12 Undang-Undang Nomor 14 Tahun 2008, menentukan: Setiap tahun Badan Publik wajib mengumumkan layanan informasi, yang meliputi: a. jumlah permintaan informasi yang diterima; b. waktu yang diperlukan Badan Publik dalam memenuhi setiap permintaan informasi; c. jumlah pemberian dan penolakan permintaan informasi; dan/atau d. alasan penolakan permintaan informasi. Pasal 13 ayat (1) dan ayat (2) Undang-Undang Nomor 14 Tahun 2008, menentukan: Untuk mewujudkan pelayanan cepat, tepat, dan sederhana setiap Badan Publik: a. menunjuk Pejabat Pengelola Informasi dan Dokumentasi; dan b. membuat dan mengembangkan sistem penyediaan layanan informasi secara cepat, mudah, dan wajar sesuai dengan petunjuk teknis standar layanan Informasi Publik yang berlaku secara nasional (ayat (1)) serta Pejabat Pengelola Informasi dan Dokumentasi dibantu oleh pejabat fungsional (ayat (2)).

Pasal 14 Undang-Undang Nomor 14 Tahun 2008, menentukan: Informasi Publik yang wajib disediakan oleh Badan Usaha Milik Negara, 
Badan Usaha Milik Daerah dan/atau badan usaha lainnya yang dimiliki oleh negara dalam undang-undang ini adalah: a. nama dan tempat kedudukan, maksud dan tujuan serta jenis kegiatan usaha, jangka waktu pendirian, dan permodalan; b. nama lengkap pemegang saham, anggota direksi, dan anggota dewan komisaris perseoran; c. laporan tahunan, laporan keuangan, neraca laporan laba rugi, dan laporan tanggung jawab sosial perusahaan yang telah diaudit; $d$. hasil penilaian oleh auditor eksternal, lembaga pemeringkat kredit dan lembaga pemeringkat lainnya; e. sistem dan alokasi dana remunerasi anggota komisi/dewan pengawas dan direksi; f. mekanisme penetapan direksi dan komisaris/dewan pengawas; g. kasus hukum yang berdasarkan undang-undang terbuka sebagai Informasi Publik; h. pedoman pelaksanaan tata kelola perusahaan yang baik berdasarkan prinsip-prinsip transparansi, akuntabilitas, pertanggungjawaban, kemandirian, dan kewajaran; i. pengumuman penerbitan efek yang bersifat utang; j. penggantian akuntan yang mengaudit perusahaan; k. perubahan tahun fiskal perusahaan; 1. kegiatan penugasan pemerintah dan/atau kewajiban pelayanan umum atau subsidi; m. mekanisme pengadaan barang dan jasa; dan/atau n. informasi lain yang ditentukan oleh undang-undang yang berkaitan dengan Badan Usaha Milik Negara/Badan Usaha Milik Daerah.

Pasal 15 Undang-Undang Nomor 14 Tahun 2008, menentukan: Informasi Publik yang wajib disediakan oleh partai politik dalam undangundang ini adalah: a. asas dan tujuan; b. program umum dan kegiatan partai politik; c. norma, alamat, dan susunan kepengurusan dan perubahannya; d. pengelolaan dan penggunaan dana yang bersumber dari APBN/APBD; e. mekanisme pengambilan keputusan partai; f. keputusan partai yang berasal dari hasil muktamar/kongres/munas dan/atau keputusan lainnya yang menurut anggaran dasar dan anggaran rumah tangga partai terbuka untuk umum; dan/atau g. informasi lain yang ditetapkan oleh undang-undang yang berkaitan dengan partai politik.

Pasal 16 Undang-Undang Nomor 14 Tahun 2008, menentukan: Informasi Publik yang wajib disediakan oleh organisasi nonpemerintah dalam undang-undang ini adalah: a. asas dan tujuan; b. program dan kegiatan organisasi; c. nama, alamat, susunan kepengurusan, dan perubahannya; d. pengelolaan dan penggunaan dana yang bersumber dari APBN dan/atau APBD, sumbangan masyarakat, dan/atau sumber luar negeri; e. mekanisme pengambilan keputusan organisasi; f. keputusankeputusan organisasi; dan/atau g. informasi lain yang diterapkan oleh peraturan perundang-undangan.

\section{Infromasi yang Dikecualikan dan Tidak Dikecualikan}

\section{Informasi yang Dikecualikan}

Pasal 17 huruf a Undang-Undang Nomor 14 Tahun 2008, menentukan: Setiap Badan Publik wajib membuka akses bagi setiap 
Pemohon Informasi Publik untuk mendapatkan Informasi Publik, kecuali: a. Informasi Publik yang apabila dibuka dan diberikan kepada Pemohon Informasi Publik dapat menghambat proses penegakan hukum, yaitu informasi yang dapat: 1) menghambat proses penyelidikan dan penyidikan suatu tindak pidana; 2) mengungkapkan identitas informan, pelapor, saksi, dan/atau korban yang mengetahui adanya tindak pidana; 3) mengungkapkan data intelijen kriminal dan rencana-rencana yang berhubungan dengan pencegahan dan penanganan segala bentuk kejahatan transnasiobal; 4) membahayakan keselamatan dan kehidupan penegak hukum dan/atau keluarganya; dan/atau 5) membahayakan keamanan peralatan, sarana, dan/atau prasarna penegak hukum.

Pasal 17 huruf b Undang-Undang Nomor 14 Tahun 2008, menentukan: Informasi Publik yang apabila dibuka dan diberikan kepada Pemohon Informasi Publik dapat mengganggu kepentingan perlindungan hak atas kekayaan intelektual dan perlindungan dari persaingan usaha tidak sehat.

Pasal 17 huruf c Undang-Undang Nomor 14 Tahun 2008, menentukan: Informasi Publik yang apabila dibuka dan diberikan kepada Pemohon Informasi Publik dapat membahayakan pertahanan dan keamanan negara, yaitu: 1) informasi tentang strategi, intelijen, operasi, taktik, dan teknik yang berkaitan dengan penyelenggaraan sistem pertahanan dan keamanan negara, meliputi tahap perencanaan, pelaksanaan, dan pengakhiran atau evaluasi dalam kaitan dengan ancaman dari dalam dan luar negeri; 2) dokumen yang memuat tentang strategi, intelijen, operasi, teknik dan taktik yang berkaitan dengan penyelenggaraan sistem pertahanan dan keamanan negara yang meliputi tahap perencanaan, pelaksanaan, dan pengakhiran atau evaluasi; 3) jumlah, komposisi, disposisi, atau dislokasi kekuatan dan kemampuan dalam penyelenggaraan sistem pertahanan dan keamanan negara serta rencana pengembangannya; 4) gambar dan data tentang situasi dan keadaan pangkalan dan/atau instalasi militer; 5) data perkiraan kemampuan militer dan pertahanan negara lain terbatas pada segala tindakan dan/atau indikasi negara tersebut yang dapat membahayakan kedaulatan NKRI dan/atau data terkait kerja sama militer dengan negara lain yang disepakati dalam perjanjian tersebut sebagai rahasia atau sangat rahasia; 6) sistem persandian negara; dan/atau 7) sistem intelijen negara.

Pasal 17 huruf d Undang-Undang Nomor 14 Tahun 2008, menentukan: Informasi Publik yang apabila dibuka dan diberikan kepada Pemohon Informasi Publik dapat mengungkapkan kekayaan alam Indonesia. Pasal 17 huruf e Undang-Undang Nomor 14 Tahun 2008, menentukan: Informasi Publik yang apabila dibuka dan diberikan kepada Pemohon Informasi Publik dapat merugikan ketahanan ekonomi nasional: 1) rencana awal pembelian dan penjualan mata uang nasional atau asing, saham, dan aset vital milik negara, 2) rencana awal perubahan nilai tukar, suku bunga, dan model operasi institusi keuangan, 3) rencana awal perubahan suku bunga bank, pinjaman pemerintah, perubahan 
pajak, tarif, atau pendapatan negara/daerah lainnya; 4) rencana awal penjualan atau pembelian tanah atau properti; 5) rencana awal investasi asing; 6) proses dan hasil pengawasan perbankan, asuransi, atau lembaga keuangan lainnya; dan/atau hal-hal yang berkaitan dengan proses percetakan uang.

Pasal 17 huruf f Undang-Undang Nomor 14 Tahun 2008, menentukan: Informasi Publik yang apabila dibuka dan diberikan kepada Pemohon Informasi Publik dapat merugikan kepentingan hubungan luar negeri: 1) posisi, daya tawar, dan strategi yang akan dan telah diambil oleh negara dalam hubungannya dengan negosiasi internasional; 2) korespondensi diplomatik antarnegara; 3) sistem komunikasi dan persandian yang dipergunakan dalam menjalankan hubungan internasional; dan/atau 4) perlindungan dan pengamanan infrastruktur strategis Indonesia di luar negeri. Pasal 17 huruf g Undang-Undang Nomor 14 Tahun 2008, menentukan: Informasi Publik yang apabila dibuka dapat mengungkapkan isi akta autentik yang bersifat pribadi dan kemaunan terakhir ataupun wasiat seseorang.

Pasal 17 huruf h Undang-Undang Nomor 14 Tahun 2008, menentukan: Informasi Publik yang apabila dibuka dan diberikan kepada Pemohon Informasi Publik dapat mengungkap rahasia pribadi, yaitu: 1) riwayat dan kondisi anggota keluarga, 2) riwayat, kondisi, dan perawatan, pengobatan kesehatan fisik, dan psikis seseorang, 3) kondisi keuangan, aset, pendapatan, dan rekening bank seseorang, 4) hasil-hasil evaluasi sehubungan dengan kapabilitas, intelektualitas, dan rekomendasi kemampuan seseorang, dan/atau 5) catatan yang menyangkut pribadi seseorang yang berkaitan dengan kegiatan satuan pendidikan formal dan sataun pendidikan nonformal. Pasal 17 huruf i Undang-Undang Nomor 14 Tahun 2008, menentukan: Memorandum atau surat-surat antar Badan Publik atau intra Badan Publik, yang menurut sifatnya dirahasiakan kecuali atas putusan Komisi Informasi atau pengadilan. Pasal 17 huruf j Undang-Undang Nomor 14 Tahun 2008, menentukan: Informasi yang tidak boleh diungkapkan berdasarkan undang-undang.

\section{Informasi Yang Tidak Dikecualikan}

Pasal 18 ayat (1) Undang-Undang Nomor 14 Tahun 2008, menentukan: Tidak termasuk dalam kategori informasi yang tidak dikecualikan adalah informasi a. putusan badan peradilan; b. ketetapan, keputusan, peraturan, surat edaran, ataupun bentuk kebijakan lain, baik yang tidak berlaku mengikat maupun mengikat ke dalam atau ke luar serta pertimbangan lembaga penegak hukum; c. surat perintah penghentian penyidikan atau penuntutan; $d$. rencana pengeluaran tahunan lembaga penegak hukum; e. laporan keuangan tahunan lembaga penegak hukum; f. laporan hasil pengembalian uang hasil korupsi; dan/atau g. informasi lain sebagaimana dimaksud dalam Pasal 11 ayat (2). 
Pasal 18 ayat (2) Undang-Undang Nomor 14 Tahun 2008, menentukan: Tidak termasuk informasi yang dikecualikan sebagaimana dimaksud dalam Pasal 17 huruf $g$ dan huruf h, antara lain apabila: a. pihak yang rahasianya diungkap memberikan persetujuan tertulis; dan/atau b. pengungkapan berkaitan dengan posisi seseorang dalam jabatan-jabatan publik. Pasal 18 ayat (3) Undang-Undang Nomor 14 Tahun 2008, menentukan: Dalam hal kepentingan pemeriksaan perkara pidana di pengadilan, Kepala Kepolisian RI, Jaksa Agung, Ketua Mahkamah Agung, Ketua Komisi Pemberantasan Korupsi, dan/atau Pimpinan Lembaga Negara Penegak Hukum lainnya yang diberi kewenangan oleh undang-undang dapat membuka informasi yang dikecualikan sebagaimana dimaksud Pasal 17 huruf a, huruf $b$, huruf $c$, huruf $d$, huruf e, huruf $f$, huruf, dan huruf j. Pasal 18 ayat (4) UndangUndang Nomor 14 Tahun 2008, menentukan: Pembukaan informasi yang dikecualikan sebagaimana dimaksud pada ayat (3) dilakukan dengan cara mengajukan permintaan izin kepada Presiden. Pasal 18 ayat (5) UndangUndang Nomor 14 Tahun 2008, menentukan: Permintaan izin sebagaimana dimaksud pada ayat (3) dan ayat (4) untuk kepentingan pemeriksaan perkara perdata yang berkaitan dengan keuangan atau kekayaan neagra di pengadilan, permintaan izin diajukan oleh Jaksa Agung sebagai pengacara negara kepada Presiden. Pasal 18 ayat (6) Undang-Undang Nomor 14 Tahun 2008, menentukan: Izin tertulis sebagaimana dimaksud pada ayat (3), ayat (4), dan ayat (5) diberikan Presiden kepada Kepala Kepolisian RI, Jaksa Agung, Ketua Mahkamah Agung, Ketua Komisi Pemberantasan Korupsi, dan/atau Pimpinan Lembaga Negara Penegak Hukum lainnya atau Ketua Mahkamah Agung. Pasal 18 ayat (7) Undang-Undang Nomor 14 Tahun 2008, menentukan: Dengan mempertimbangkan kepentingan pertahanan dan keamanan negara dan kepentingan umum, Presiden dapat menolak permintaan informasi yang dikecualikan sebagaimana dimaksud pada ayat (3), ayat (4), dan ayat (5).

\section{Mekanisme Memperoleh Informasi}

Pasal 21 Undang-Undang Nomor 14 Tahun 2008, menentukan: Mekanisme untuk memperoleh Informasi Publik didasarkan pada prinsip cepat, tepat waktu, dan biaya ringan. Pasal 22 ayat (1) sampai dengan ayat (9) Undang-Undang Nomor 14 Tahun 2008, mengatur: (1) Setiap Pemohon Informasi Publik dapat mengajukan permintaan untuk memperoleh Informasi Publik kepada Badan Publik terkait secara tertulis atau tidak tertulis; (2) Badan Publik wajib mencatat nama dan alamat Pemohon Informasi Publik, subyek dan format informasi serta cara penyampaian informasi yang diminta oleh Pemohon Informasi Publik; (3) Badan Publik wajib mencatat permintaan Informasi Publik yang diajukan secara tidak tertulis; (4) Badan Publik wajib memberikan tanda bukti penerimaan permintaan Informasi Publik berupa nomor pendaftaran permintaan Informasi Publik berupa nomor pendaftaran 
pada saat permintaan diterima; (5) Dalam hal permintaan disampaikan secara langsung atau melalui surat elektronik, nomor pendaftaran diberikan saat penerimaan permintaan; (6) Dalam hal permintaan disampaikan melalui surat, pengiriman nomor pendaftaran dapat diberikan bersamaan dengan pengiriman informasi; (7) Paling lambat 10 hari kerja sejak diterimanya permintaan, Badan Publik wajib menyampaikan pemberitahuan tertulis yang berisikan: a. informasi yang diminta berada di bawah penguasaannya ataupun tidak; $b$. Badan Publik wajib memberitahukan Badan Publik yang menguasasi informasi yang diminta apabila informasi yang diminta tidak berada di bawah penguasaannya dan Badan Publik yang menerima permintaan mengetahui keberadaan informasi yang diminta; c. penerimaan atau penolakan permintaan dengan alasan yang tercantum dalam Pasal 17; d. dalam hal permintaan diterima seluruhnya atau sebagian dicantumkan materi informasi yang akan diberikan; e. dalam hal suatu dokumen mengandung materi yang dikecualikan sebagaimana dimaksud dalam Pasal 17, maka informasi yang dikecualikan dapat dihitamkan disertai alasan dan materinya; f. alat penyampai dan format informasi yang akan diberikan; dan/atau g. biaya dan cara pembayaran untuk memperoleh informasi yang diminta; (8) Badan Publik dapat memperpanjang waktu untuk mengirimkan pemberitahuan paling lambat 7 hari kerja dengan memberikan alasan secara tertulis.

\section{Komisi Informasi}

\section{Fungsi Komisi Informasi}

Pasal 23 dan Pasal 1 angka 5 Undang-Undang Nomor 14 tahun 2008, menentukan: Komisi Informasi adalah lembaga mandiri yang berfungsi menjalankan undang-undang ini dan peraturan pelaksanananya menetapkan petunjuk teknis standar layanan Informasi Publik dan menyelesaikan Sengketa Informasi Publik melalui Mediasi dan/atau Ajudikasi nonlitigasi.

\section{Kedudukan Komisi Informasi}

Pasal 24 ayat (1) Undang-Undang Nomor 14 tahun 2008, menentukan: (1) Komisi Informasi terdiri atas Komisi Informasi Pusat, Komisi Informasi Provinsi, dan jika dibutuhkan Komisi Informasi Kabupaten/Kota.

\section{Susunan Komisi Informasi}

Pasal 25 Undang-Undang Nomor 14 tahun 2008, menentukan: (1) Anggota Komisi Informasi Pusat 7 orang mencerminkan unsur pemerintah dan unsur masyarakat; (2) Anggota Komisi Informasi Provinsi dan/atau Komisi Informasi Kabupaten/Kota 5 orang mencerminkan unsur pemerintah dan unsur masyarakat. 


\section{Tugas Komisi Informasi}

Pasal 26 ayat (1) Undang-Undang Nomor 14 tahun 2008, menentukan: Komisi Informasi bertugas: a. menerima, memeriksa, dan memutus permohonan penyelesaian Sengketa Informasi Publik melalui Mediasi dan/atau Ajudikasi nonlitigasi yang diajukan oleh setiap Pemohon Informasi Publik; b. menetapkan kebijakan umum pelayanan Informasi Publik; dan c. menetapkan petunjuk pelaksanaan dan petunjuk teknis.

Pasal 26 ayat (2) Undang-Undang Nomor 14 tahun 2008, menentukan: Komisi Informasi Pusat bertugas: a. menetapkan prosedur pelaksanaan penyelesaian sengketa melalui Mediasi dan/atau Ajudikasi nontiligasi; b. menerima, memeriksa, dan memutus Sengketa Informasi Publik di daerah selama Komisi Informasi provinsi dan/atau Komisi Informasi kabupaten/kota belum terbentuk; dan c. memberikan laporan mengenai pelaksanaan tugasnya berdasarkan undang-undang ini kepada Presiden dan DPR RI setahun sekali atau sewaktu-waktu jika diminta. Pasal 26 ayat (3) Undang-Undang Nomor 14 Tahun 2008, menentukan: Komisi Informasi provinsi dan/atau Komisi Informasi kabupaten/kota bertugas menerima, memeriksa, dan memutus Sengketa Informasi Publik di daerah melalui Mediasi dan/atau Ajudikasi nonlitigasi.

Pasal 1 angka 5 Undang-Undang Nomor 14 Tahun 2008, merumuskan: "Sengketa Informasi Publik adalah sengketa yang terjadi antara badan publik dan pengguna informasi publik yang berkaitan dengan hak memperoleh dan menggunakan informasi berdasarkan peraturan perundang-undangan". Pasal 1 angka 11 Undang-Undang Nomor 14 Tahun 2008, merumuskan: "Pengguna Informasi Publik adalah orang yang menggunakan informasi publik ...". Pasal 1 angka 12 Undang-Undang Nomor 14 Tahun 2008, merumuskan: "Pemohon Informasi Publik adalah warga negara dan/atau badan hukum Indonesia yang mengajukan permintaan informasi publik ...". Pasal 1 angka 6 Undang-Undang Nomor 14 Tahun 2008, merumuskan: "Mediasi adalah penyelesaian sengketa informasi publik antara para pihak melalui bantuan mediator komisi informasi". Pasal 1 angka 7 Undang-Undang Nomor 14 Tahun 2008, merumuskan: "Ajudikasi adalah proses penyelesaian sengketa informasi publik antara para pihak yang diputus oleh komisi informasi". Pasal 1 angka 8 Undang-Undang Nomor 14 Tahun 2008, merumuskan: "Pejabat publik adalah orang yang ditunjuk dan diberi tugas untuk menduduki posisi atau jabatan tertentu pada badan publik. Pasal 1 angka 10 Undang-Undang Nomor 14 Tahun 2008, merumuskan: "Orang adalah orang perseorangan, kelompok orang, badan hukum, atau badan publik ...". Pasal 1 angka 9 Undang-Undang Nomor 14 Tahun 2008, merumuskan: "Pejabat Pengelola Informasi dan Dokumentasi adalah pejabat yang bertanggung jawab di bidang penyimpanan, pendokumentasian, penyediaan, dan/atau pelayanan informasi di badan publik". 


\section{Wewenang Komisi Informasi}

Pasal 27 ayat (1) Undang-Undang Nomor 14 Tahun 2008, menentukan: Dalam menjalankan tugasnya, Komisi Informasi memiliki wewenang: a. memanggil dan/atau mempertemukan para pihak yang bersengketa; b. meminta catatan atau bahan yang relevan yang dimiliki oleh Badan Publik terkait untuk mengambil keputusan dalam upaya menyelesaikan Sengketa Informasi Publik; c. meminta keterangan atau menghadirkan pejabat Badan Publik ataupun pihak yang terkait sebagai saksi dalam penyelesaian Sengketa Informasi Publik; d. mengambil sumpah setiap saksi yang didengar keterangannya dalam Ajudikasi nonlitigasi penyelesaian Sengketa Informasi Publik; dan e. membuat kode etik yang diumumkan kepada publik sehingga masyarakat dapat menilai kinerja Komisi Informasi.

Pasal 27 ayat (2) Undang-Undang Nomor 14 Tahun 2008, menentukan: Kewenangan Komisi Informasi Pusat meliputi kewenangan penyelesaian Sengketa Informasi Publik yang menyangkut Badan Publik pusat dan Badan Publik tingkat provinsi dan/atau Badan Publik tingkat kabupaten/kota selama Komisi Informasi di provinsi atau Komisi Informasi kabupaten/kota tersebut belum terbentuk. Pasal 27 ayat (3) Undang-Undang Nomor 14 Tahun 2008, menentukan: Kewenangan Komisi Informasi provinsi meliputi kewenangan penyelesaian sengketa yang menyangkut Badan Publik tingkat provinsi yang bersangkutan. Pasal 27 ayat (4) Undang-Undang Nomor 14 Tahun 2008, menentukan: Kewenangan Komisi Informasi kabupaten/kota meliputi kewenangan penyelesaian sengketa yang menyangkut Badan Publik tingkat kabupaten/kota yang bersangkutan.

\section{Pertanggungjawaban Komisi Informasi}

Pasal 28 ayat (1) Undang-Undang Nomor 14 Tahun 2008, menentukan: Komisi Informasi Pusat bertanggung jawab kepada Presiden dan menyampaikan laporan tentang pelaksanaan fungsi, tugas, dan wewenangnya kepada Dewan Perwakilan Rakyat Republik Indonesia. Pasal 28 ayat (2) Undang-Undang Nomor 14 Tahun 2008, menentukan: Komisi Informasi provinsi bertanggung jawab kepada gubernur dan menyampaikan laporan tentang pelaksanaan fungsi, tugas, dan wewenangnya kepada Dewan Perwakilan Rakyat Daerah provinsi yang bersangkutan. Pasal 28 ayat (3) Undang-Undang Nomor 14 Tahun 2008, menentukan: Komisi Informasi kabupaten/kota bertanggung jawab kepada bupati/walikota dan menyampaikan laporan tentang pelaksanaan fungsi, tugas, dan wewenangnya kepada Dewan Perwakilan Rakyat Daerah kabupaten/kota yang bersangkutan. Laporan lengkap Komisi Informasi bersifat terbuka untuk umum (Pasal 28 ayat (4) UndangUndang Nomor 14 Tahun 2008). 


\section{Pengangkatan dan Pemberhentian Anggota Komisi Informasi}

Pasal 30 ayat (2) Undang-Undang Nomor 14 Tahun 2008, menentukan: Rekrutmen calon anggota Komisi Informasi dilaksanakan oleh Pemerintah secara terbuka, jujur, dan obyektif. Pasal 30 ayat (3) Undang-Undang Nomor 14 Tahun 2008, menentukan: Daftar calon anggota Komisi Informasi wajib diumumkan kepada masyarakat. Setiap orang berhak mengajukan pendapat dan penilaian terhadap calon anggota Komisi Informasi dengan disertai alasan (Pasal 30 ayat (4) UndangUndang Nomor 14 Tahun 2008). Pasal 30 ayat (1) huruf h UndangUndang Nomor 14 Tahun 2008, menentukan: syarat pengangkatan anggota Komisi Informasi berusia paling rendah 35 tahun.

Pasal 31 ayat (1) Undang-Undang Nomor 14 Tahun 2008, menentukan: Calon anggota Komisi Informasi Pusat hasil rekrutmen diajukan kepada Dewan Perwakilan Rakyat RI oleh Presiden sejumlah 21 orang calon. Pasal 31 ayat (2) Undang-Undang Nomor 14 Tahun 2008, menentukan: Dewan Perwakilan Rakyat RI memilih anggota Komisi Informasi Pusat melalui uji kepatutan dan kelayakan. Anggota Komisi Informasi Pusat yang telah dipilih oleh Dewan Perwakilan Rakyat RI selanjutnya ditetapkan oleh Presiden.

Pasal 32 ayat (1) Undang-Undang Nomor 14 Tahun 2008, menentukan: Calon anggota Komisi Informasi provinsi dan/atau Komisi Informasi kabupaten/kota hasil rekrutmen diajukan kepada Dewan Perwakilan Rakyat Daerah provinsi dan/atau Dewan Perwakilan Rakyat Daerah kabupaten/kota oleh gubernur dan/atau bupati/walikota paling sedikit 10 calon dan paling banyak 15 orang calon. Pasal 32 ayat (2) Undang-Undang Nomor 14 Tahun 2008, menentukan: Dewan Perwakilan Rakyat Daerah provinsi dan/atau Dewan Perwakilan Rakyat Daerah kabupaten/kota memilih anggota Komisi Informasi provinsi dan/atau Komisi Informasi kabupaten/kota melalui uji kelayakan dan kepatutan. Anggota Komisi Informasi provinsi dan/atau Komisi Informasi kabupaten/kota yang telah dipilih oleh Dewan Perwakilan Rakyat Daerah Provinsi dan/atau Dewan Perwakilan Rakyat Daerah kabupaten/kota selanjutnya ditetapkan oleh gubernur dan/atau bupati/walikota (Pasal 32 ayat (3) Undang-Undang Nomor 14 Tahun 2008). Anggota Komisi Informasi diangkat untuk masa jabatan 4 tahun dan dapat diangkat kembali untuk satu periode berikutnya (Pasal 33 Undang-Undang Nomor 14 Tahun 2008).

Pasal 34 ayat (1) Undang-Undang Nomor 14 Tahun 2008, menentukan: Pemberhentian anggota Komisi Informasi dilakukan berdasarkan keputusan Komisi Informasi sesuai dengan tingkatannya dan diusulkan kepada Presiden untuk Komisi Informasi Pusat, kepada gubernur untuk Komisi Informasi provinsi, dan kepada bupati/walikota untuk Komisi Informasi kabupaten/kota untuk ditetapkan. Pasal 34 ayat (3) Undang-Undang Nomor 14 Tahun 2008, menentukan: Pemberhentian ditetapkan melalui Keputusan Presiden untuk Komisi Informasi Pusat, 
keputusan gubernur untuk Komisi Informasi provinsi, dan/atau keputusan bupati/walikota untuk Komisi Informasi kabupaten/kota. Pasal 34 ayat (4) Undang-Undang Nomor 14 Tahun 2008, menentukan: Pergantian antarwaktu anggota Komisi Informasi dilakukan oleh Presiden setelah berkonsultasi dengan pimpinan Dewan Perwakilan Rakyat RI untuk Komisi Informasi Pusat, oleh gubernur setelah berkonsultasi dengan pimpinan Dewan Perwakilan Rakyat Daerah provinsi untuk Komisi Informasi provinsi, dan oleh bupati/walikota setelah berkonsultasi dengan pimpinan Dewan Perwakilan Rakyat Daerah kabupaten/kota untuk Komisi Informasi kabupaten/kota. Anggota Komisi Informasi pengganti antarwaktu diambil dari urutan berikutnya berdasarkan hasil uji kelayakan dan kepatutan yang telah dilaksanakan sebagai dasar pengangkatan anggota Komisi Informasi pada periode dimaksud.

\section{Keberatan dan Penyelesaian Sengketa Melalui Komisi Informasi}

\section{Keberatan}

Pasal 35 ayat (1) Undang-Undang Nomor 14 Tahun 2008, menentukan: Setiap Pemohon Informasi Publik dapat mengajukan keberatan secara tertulis kepada atasan Pejabat Pengelola Informasi dan Dokumenatsi berdasarkan alasan: a. penolakan atas permintaan informasi berdasarkan alasan pengecualian sebagaimana dimaksud dalam Pasal 17; b. tidak disediakannya informasi berkala sebagaimana dimaksud dalam Pasal 9; c. tidak ditanggapinya permintaan informasi; d. permintaan informasi ditanggapi tidak sebagaimana yang diminta; e. tidak dipenuhinya permintaan informasi; f. pengenaan biaya yang tidak wajar; dan/atau g. penyampaian informasi yang melebihi waktu yang diatur dalam undang-undang ini. Alasan sebagaimana dimaksud pada ayat (1) huruf b sampai dengan huruf $\mathrm{g}$ dapat diselesaikan secara musyawarah oleh kedua belah pihak (Pasal 35 ayat (2) Undang-Undang Nomor 14 Tahun 2008).

Pasal 36 ayat (1) Undang-Undang Nomor 14 Tahun 2008, menentukan: Keberatan diajukan oleh Pemohon Informasi Publik dalam jangka waktu paling lambat 30 hari kerja setelah ditemukannya alasan sebagaimana dimaksud dalam Pasal 35 ayat (1). Pasal 36 ayat (2) Undang-Undang Nomor 14 Tahun 2008, menentukan: Atasan pejabat sebagaimana dimaksud dalam Pasal 35 ayat (1) memberikan tanggapan atas keberatan yang diajukan oleh Pemohon Informasi Publik dalam jangka waktu paling lambat 30 hari kerja sejak diterimanya keberatan secara tertulis. Alasan tertulis disertakan bersama tanggapan apabila atasan pejabat sebagaimana dimaksud dalam Pasal 35 ayat (1) menguatkan putusan yang ditetapkan oleh bawahannya (Pasal 36 ayat (3) Undang-Undang Nomor 14 Tahun 2008). 


\section{Penyelesaian Sengketa Melalui Komisi Informasi}

Pasal 37 ayat (1) Undang-Undang Nomor 14 Tahun 2008, menentukan: Upaya penyelesaian Sengketa Informasi Publik diajukan kepada Komisi Informasi Pusat dan/atau Komisi Informasi provinsi dan/atau Komisi Informasi kabupaten/kota sesuai dengan kewenangannya apabila tanggapan atasan Pejabat Pengelola Informasi dan Dokumentasi dalam proses keberatan tidak memuaskan Pemohon Informasi Publik. Upaya penyelesaian sengketa Informasi Publik diajukan dalam waktu paling lambat 14 hari kerja setelah diterimanya tanggapan tertulis dari atasan pejabat sebagaimana dimaksud dalam Pasal 36 ayat (1). (Pasal 27 ayat (2) Undang-Undang Nomor 14 Tahun 2008).

Pasal 38 ayat (1) Undang-Undang Nomor 14 Tahun 2008, menentukan: Komisi Informasi Pusat dan Komisi Informasi provinsi dan/atau Komisi Informasi kabupaten/kota harus mulai mengupayakan penyelesaian Sengketa Informasi Publik melalui Mediasi dan/atau Ajudikasi nonlitigasi paling lambat 14 hari kerja setelah menerima permohonan penyelesaian Sengketa Informasi Publik. Pasal 38 ayat (2) Undang-Undang Nomor 14 Tahun 2008, menentukan: Proses penyelesaian sengketa paling lambat dapat diselesaikan dalam waktu 100 hari. Putusan Komisi Informasi yang berasal dari kesepakatan melalui Mediasi bersifat final dan mengikat.

\section{Hukum Acara Komisi}

\section{Mediasi}

Pasal 40 ayat (1) Undang-Undang Nomor 14 Tahun 2008, menentukan: Penyelesaian sengketa melalui Mediasi merupakan pilihan para pihak dan bersifat sukarela. Pasal 40 ayat (2) Undang-Undang Nomor 14 Tahun 2008, menentukan: Penyelesaian sengketa melalui Mediasi hanya dapat dilakukan terhadap perkara yang terdapat dalam Pasal 35 ayat (1) huruf b sampai dengan huruf g. Pasal 40 ayat (3) Undang-Undang Nomor 14 Tahun 2008, menentukan: Kesepakatan para pihak dalam proses Mediasi dituangkan dalam bentuk putusan Mediasi Komisi Informasi. Dalam proses Mediasi anggota Komisi Informasi berperan sebagai mediator (Pasal 41 Undang-Undang Nomor 14 Tahun 2008).

\section{Ajudikasi}

Pasal 42 Undang-Undang Nomor 14 Tahun 2008, menentukan: Penyelesaian Sengketa Informasi Publik melalui Ajudikasi nonlitigasi oleh Komisi Informasi hanya dapat ditempuh apabula upaya Mediasi dinyatakan tidak berhasil secara tertulis oleh salah satu atau para pihak yang bersengketa, atau salah satu atau para pihak yang bersengketa 
menarik diri dari perundingan. Pasal 43 ayat (1) sampai dengan ayat (4) Undang-Undang Nomor 14 Tahun 2008, menentukan: (1) Sidang Komisi Informasi yang memeriksa dan memutus perkara paling sedikit 3 orang anggota komisi atau lebih dan harus berjumlah gasal; (2) Sidang Komisi Informasi bersifat terbuka untuk umum; (3) Dalam hal pemeriksaan yang berkaitan dengan dokumen-dokumen yang termasuk pengecualian sebagaimana dimaksud dalam Pasal 17, maka sidang pemeriksaan perkara bersifat tertutup; (4) Anggota Komisi Informasi wajib menjaga rahasia dokumen tersebut.

\section{Pemeriksaan}

Pasal 44 ayat (1) sampai dengan ayat (4) Undang-Undang Nomor 14 Tahun 2008, menentukan: (1) Dalam hal Komisi Informasi menerima permohonan penyelesaian Sengketa Informasi Publik, Komisi Informasi memberikan salinan permohonan kepada pihak termohon; (2) Pihak termohon adalah pimpinan Badan Publik atau pejabat terkait yang ditunjuk yang didengar keterangannya dalam proses pemeriksaan; (3) Komisi Informasi dapat memutus untuk mendengar keterangan secara lisan atau tertulis; (4) Pemohon Informasi Publik dan termohon dapat mewakilkan kepada wakilnya yang secara khusus dikuasakan untuk itu.

\section{Pembuktian}

Pasal 45 ayat (1) dan ayat (2) Undang-Undang Nomor 14 Tahun 2008, menentukan: (1) Badan Publik harus membuktikan hal-hal yang mendukung pendapatnya apabila menyatakan tidak dapat memberikan informasi dengan alasan sebagaimana dimaksud dalam Pasal 17 dan Pasal 35 ayat (1) huruf a; (2) Badan Publik harus menyampaikan alasan yang mendukung sikapnya apabila Pemohon Informasi Publik mengajukan permohonan penyelesaian Sengketa Informasi Publik sebagaimana diatur dalam Pasal 35 ayat (1) huruf b sampai dengan huruf g.

\section{Putusan Komisi Informasi}

Pasal 46 ayat (1) Undang-Undang Nomor 14 Tahun 2008, menentukan: Putusan Komisi Informasi tentang pemberian atau penolakan akses terhadap seluruh atau sebagian informasi yang diminta berisikan salah satu perintah: a. membatalkan putusan atasan Badan Publik dan memutuskan untuk memberikan sebagian atau seluruh informasi yang diminta oleh Pemohon Informasi Publik sesuai dengan keputusan Komisi Informasi; atau b. mengukuhkan putusan atasan Pejabat Pengelola Informasi dan Dokumentasi untuk tidak memberikan informasi yang diminta sebagian atau seluruhnya sebagaimana dimaksud dalam Pasal 17. 
Pasal 46 ayat (2) Undang-Undang Nomor 14 Tahun 2008, menentukan: Putusan Komisi Informasi tentang pokok keberatan sebagaimana dimaksud dalam Pasal 35 ayat (1) huruf b sampai dengan huruf $g$ berisikan salah satu perintah: a. memerintahkan Pejabat Pengelola Informasi dan Dokumentasi untuk menjalankan kewajibannya sebagaimana ditentukan dalam undang-undang ini; b. memerintahkan Badan Publik untuk memenuhi kewajibannya dalam jangka waktu pemberian informasi sebagaiman diatur dalam undang-undang ini; atau c. mengukuhkan pertimbangan atasan Badan Publik atau memutuskan mengenai biaya penelusuran dan/atau penggandaan informasi. Pasal 46 ayat (5) Undang-Undang Nomor 14 Tahun 2008, menentukan: Apabila ada anggota komisi yang dalam memutus suatu perkara memiliki pendapat yang berbeda dari putusan yang diambil, pendapat anggota komisi tersebut dilampirkan dalam putusan dan menjadi bagian tidak terpisahkan dari putusan tersebut.

\section{Gugatan Ke Pengadilan dan Kasasi}

\section{Gugatan ke Pengadilan}

Pasal 47 ayat (1) dan ayat (2) Undang-Undang Nomor 14 Tahun 2008, menentukan: (1) Pengajuan gugatan dilakukan melalui pengadilan tata usaha negara apabila yang digugat Badan Publik negara; (2) Pengajuan gugatan dilakukan melalui pengadilan negeri apabila yang digugat Badan Publik selain Badan Publik negara.

Pasal 48 ayat (1) dan ayat (2) Undang-Undang Nomor 14 Tahun 2008, menentukan: (1) Pengajuan gugatan hanya dapat ditempuh apabila salah satu atau para pihak yang bersengketa secara tertulis menyatakan tidak menerima putusan Ajudikasi dari Komisi Informasi paling lambat 14 hari kerja setelah diterimanya putusan; (2) Sepanjang menyangkut informasi yang dikecualikan, sidang di Komisi Informasi dan di pengadilan bersifat tertutup.

Pasal 49 ayat (1) Undang-Undang Nomor 14 Tahun 2008, menentukan: Putusan pengadilan tata usaha negara atau pengadilan negeri dalam penyelesaian Sengketa Informasi Publik tentang pemberian atau penolakan akses terhadap seluruh atau sebagian informasi yang diminta berisi salah satu perintah: a. membatalkan putusan Komisi Informasi dan/atau memerintahkan Badan Publik: (1) memberikan sebagian atau seluruh informasi yang dimohonkan oleh Pemohon Informasi Publik; atau (2) menolak memberikan sebagain atau seluruh informasi yang diminta oleh Pemohon Informasi Publik; b. menguatkan putusan Komisi Informasi dan/atau memerintahkan Badan Publik: (1) memberikan sebagian atau seluruh informasi yang diminta oleh Pemohon Informasi Publik; atau (2) menolak memberikan sebagian atau seluruh informasi yang diminta oleh Pemohon Informasi Publik. 
Pasal 49 ayat (2) Undang-Undang Nomor 14 Tahun 2008, menentukan: Putusan pengadilan tata usaha negara atau pengadilan negeri dalam penyelesaian Sengketa Informasi Publik tentang pokok keberatan sebagaimana dimaksud dalam Pasal 35 ayat (1) huruf b sampai dengan huruf $\mathrm{g}$ berisi salah satu perintah: a. memerintahkan Pejabat Pengelola Informasi dan Dokumentasi untuk menjalankan kewajibannya sebagaimana ditentukan dalam undang-undang ini dan/atau memerintahkan untuk memenuhi jangka waktu pemberian informasi sebagaimana diatur dalam undang-undang ini; $b$. menolak permohonan Pemohon Publik; c. memutuskan biaya penggandaan informasi; atau d. pengadilan tata usaha negara atau pengadilan negeri memberikan salinan putusan kepada para pihak yang bersengketa.

\section{Kasasi}

Pasal 50 Undang-Undang Nomor 14 Tahun 2008, menentukan: Pihak yang tidak menerima putusan pengadilan tata usaha negara atau pengadilan negeri dapat mengajukan kasasi kepada Mahkamah Agung paling lambat dalam waktu 14 hari sejak diterimanya putusan pengadilan tata usaha negara atau pengadilan negeri.

\section{Ketentuan Pidana}

Pasal 51 Undang-Undang Nomor 14 Tahun 2008, menentukan: Setiap orang yang dengan sengaja menggunakan Informasi Publik secara melawan hukum dipidana dengan pidana penjara paling lama 1 tahun dan/atau denda paling banyak Rp 5.000.000,00.

Pasal 52 Undang-Undang Nomor 14 Tahun 2008, menentukan: Badan Publik yang dengan sengaja tidak menyediakan, tidak memberikan, dan/atau tidak menerbitkan Informasi Publik berupa Informasi Publik secara berkala, Informasi Publik yang wajib diumumkan secara serta-merta, Informasi Publik yang wajib tersedia setiap saat, dan/atau Informasi Publik yang harus diberikan atas dasar permintaan sesuai dengan undang-undang ini, dan mengakibatkan kerugian bagi orang lain dikenakan pidana kurungan paling lama 1 tahun dan/atau pidana denda paling banyak Rp 5.000.000,00.

Pasal 53 Undang-Undang Nomor 14 Tahun 2008, menentukan: Setiap orang yang dengan sengaja atau melawan hukum menghancurkan, merusak, dan/atau menghilangkan dokumen Informasi Publik dalam bentuk media apa pun yang dilindungi negara dan/atau yang berkaitan dengan kepentingan umum dipidana dengan pidana penjara paling lama 2 tahun dan/atau pidana denda paling banyak $\mathrm{Rp} 10.000 .000,00$.

Pasal 54 ayat (1) Undang-Undang Nomor 14 Tahun 2008, menentukan: Setiap orang yang dengan sengaja dan tanpa hak mengakses dan/atau memberikan informasi yang dikecualikan sebagaimana diatur dalam Pasal 17 huruf $a$, huruf $b$, huruf $d$, huruf $f$, huruf $g$, huruf $h$, huruf $i$, dan huruf $j$, dipidana 
dengan pidana penjara paling lama 2 tahun dan/atau pidana denda paling banyak $\operatorname{Rp} 10.000 .000,00$.

Pasal 54 ayat (2) Undang-Undang Nomor 14 Tahun 2008, menentukan: Setiap orang yang dengan sengaja dan tanpa hak mengakses dan/atau memperoleh dan/atau memberikan informasi yang dikecualikan sebagaimana diatur dalam Pasal 17 huruf $\mathrm{c}$ dan huruf e, dipidana dengan pidana penjara paling lama 3 tahun dan/atau pidana denda paling banyak Rp 20.000.000,00.

Pasal 55 Undang-Undang Nomor 14 Tahun 2008, menentukan: Setiap orang yang dengan sengaja membuat Informasi Publik yang tidak benar atau menyesatkan dan mengakibatkan kerugian bagi oranglain dipidana dengan pidana penjara paling lama 1 tahun dan/atau pidana denda paling banyak $\mathrm{Rp}$ $5.000 .000,00$.

Pasal 56 Undang-Undang Nomor 14 Tahun 2008, menentukan: Setiap pelanggaran yang dikenai sanksi pidana dalam undang-undang ini dan juga diancam dengan sanksi pidana dalam undang-undang lain yang bersifat khusus, yang berlaku adalah sanksi pidana dari undang-undang yang lebih khusus tersebut.

Pasal 57 Undang-Undang Nomor 14 Tahun 2008, menentukan: Tuntutan pidana berdasarkan undang-undang ini merupakan delik aduan dan diajukan melalui peradilan umum.

\section{Penutup}

Informasi publik sebagaimana diatur dalam Undang-Undang Nomor 14 Tahun 2008 tentang Keterbukaan Informasi Publik ini sangat penting dalam rangka (1) memenuhi kebutuhan pokok setiap orang bagi pengembangan pribadi; (2) merupakan kebutuhan pokok bagi pengembangan lingkungan sosial, (3) memperoleh informasi merupakan HAM, (4) keterbukaan informasi merupakan ciri penting negara demokrastis, (5) keterbukaan informasi merupakan sarana mengoptimalkan pengawasan publik, (6) pengelolaan informasi mengembangkan masyarakat informasi, (7) mendorong pengembangan ilmu pengetahuan, teknologi, dan seni (ipteks), serta (8) mencerdaskan kehidupan bangsa. 


\section{Daftar Pustaka}

Anwar, Chaerul. Konstitusi dan Kelembagaan Negara, Jakarta: CV. Novindo Pustaka Mandiri, 1999.

Asshiddiqie, Jimly. Konstitusi \& Konstitutionalisme Indonesia, Cetakan Pertama, Jakarta: Sekretariat Jenderal dan Kepaniteraan Mahkamah Konstitusi RI, 2005.

Budiardjo, Miriam. Dasar-dasar Ilmu Politik, Cetakan VI (Diterbitkan pertama kali 1972, Cetakan I 1977), Jakarta: PT. Gramedia, 1981.

Departemen Pendidikan dan Kebudayaan RI, Kamus Besar Bahasa Indonesia, Edisi Kedua, Cetakan Ketiga, Jakarta: Balai Pustaka, 1994.

Dicey, Albert Venn, An Introduction to Study of The Law of The Constitution, Tenth Edition (First Edition 1885), London: English Language Book Society and Macmillan, 1952.

Echols, John M. dan Hassan Shadily, Kamus Inggris Indonesia, Jakarta: PT. Gramedia,

Indra, H. Muhammad Ridhwan. Undang-Undang Dasar 1945 Sebagai Karya Manusia, Jakarta: Pustaka Sinar Harapan, 1990.

Godechot, Jacques, Les Constitutions de La France Depuis 1789, Paris: Garnier-Flammarion, 1982.

Kusumaatmadja, Mochtar. Fungsi Dan Perkembangan Hukum Dalam Pembangunan Nasional, Bandung: Binacipta, 1970.

Kelsen, Hans, General Theory of Law and State, Translated by Assistant Professor of Philosophy in the University of Stockholm Anders Wedberg, Copyright 1945, Copyright Renewed 1973, New York: Russell \& Russell, 1973.

Mahfud MD., Mohammad. Demokrasi dan Konstitusi Di Indonesia Studi Tentang Interaksi Politik dan Kehidupan Ketatanegaraan, Jakarta: PT. Rineka Cipta, Cetakan Kedua (Cetakan Pertama 1993), 2000.

Manan, Bagir. Pertumbuhan dan Perkembangan Konstitusi Suatu Negara, Bandung: CV. Mandar Maju, 1995.

. Teori dan Politik Konstitusi, Cetakan Kedua (Cetakan Pertama 2003), Yogyakarta: Fakultas Hukum UII Press, 2004.

Martosoewignjo, R. Sri Soemantri, Prosedur dan Sistem Perubahan Konstitusi, Cetakan IV (Cetakan I 1978), Bandung: PT. Alumni, 1987.

Murphy, Walter F., James E.Fleming, and Sotirios A.Barber, American Constitutional Interpretation, Second Edition, New York: The Foundation, Inc., 1995.

Prodjodikoro, R. Wirjono. Asas-asas Hukum Tata Negara Di Indonesia, Cetakan Ketiga (Cetakan Pertama 1970), Jakarta: PT. Dian Rakyat, 1977. 
Riyanto, Astim. Teori Konstitusi, Cetakan Keempat (Cetakan Pertama 1993), Bandung: Yapemdo, 2009.

. Kapita Selekta Hukum Konstitusi, Cetakan Pertama, Bandung: Yapemdo, 2009.

. Kapita Selekta Hukum Dalam Dinamika, Cetakan Ketiga (Cetakan Pertama 2000), Bandung: Yapemdo, 2010.

. Filsafat Hukum, Cetakan Ketiga (Cetakan Pertama 2003), Bandung: Yapemdo, 2010.

. Teori Negara Kesatuan, Cetakan Kedua (Cetakan Pertama 2006), Bandung: Yapemdo, 2010.

Negara Kesatuan Konsep, Asas, dan Aktualisasinya, Cetakan Kedua (Cetakan Pertama 2006), Bandung: Yapemdo, 2010.

. Kapita Selekta Politik Kesejahteraan, Cetakan Kedua (Cetakan Pertama 2009), Bandung: Yapemdo, 2010.

Sastrosoehardjo, Soehardjo. Konstitusi \& Demokrasi Beberapa Pemikiran Tentang Hukum, Semarang: Dahara Prize, 1991.

South-East Asian and Pacific Conference of Jurists, Bangkok, February, 15-19, 1965, The Dynamic Aspects of the Rule of Law in the Modern Age, Bangkok: International Commission of Jurists, 1965.

Strong, C.F., Modern Political Constitutions An Introduction to the Comparative Study of their History and Existing Form, Fifth (Revised) Edition 1958, Second Impression (First Printed 1930), London: Sidgwick \& Jackson Limited, 1960.

Thaib, Dahlan, Jazim Hamidi, dan Ni'matul Huda, Teori Hukum dan Konstitusi, Jakarta: PT. Raja Grafinso Persada, 1999.

Wahjono, Padmo. Indonesia Negara Berdasarkan Atas Hukum, Jakarta: Ghalia Indonesia, 1983.

Wheare, Kenneth C., Modern Constitutions, Third Impression (First Published 1951), London, New York, Toronto: Oxford University Press, 1975.

Yamin, Muhammad. Naskah-Persiapan Undang-Undang Dasar 1945, Jakarta: Yayasan Prapantja, 1959.

\section{Peraturan Perundang-undangan}

Republik Indonesia. Undang-Undang Dasar Negara Republik Indonesia Tahun 1945, Lembaran Negara Republik Indonesia Tahun 1959 Nomor 75.

. Perubahan Pertama Undang-Undang Dasar Negara Republik Indonesia Tahun 1945, Ditetapkan oleh Majelis Permusyawaratan Rakyat Republik Indonesia di Jakarta tanggal 19 Oktober 1999. 
- Perubahaan Kedua Undang-Undang Dasar Negara Republik Indonesia Tahun 1945, Ditetapkan oleh Majelis Permusyawaratan Rakyat Republik Indonesia di Jakarta pada tanggal 18 Agustus 2000.

- Perubahaan Ketiga Undang-Undang Dasar Negara Republik Indonesia Tahun 1945, Ditetapkan oleh Majelis Permusyawaratan Rakyat Republik Indonesia di Jakarta pada tanggal 9 November 2001.

. Perubahaan Keempat Undang-Undang Dasar Negara Republik Indonesia Tahun 1945, Ditetapkan oleh Majelis Permusyawaratan Rakyat Republik Indonesia di Jakarta pada tanggal 10 Agustus 2002.

. Undang-Undang Republik Indonesia Nomor 14 Tahun 2008 tanggal 30 April 2008 tentang Keterbukaan Informasi Publik.

Keputusan Presiden Republik Indonesia Nomor 153 Tahun 1999 tanggal 7 Desember 1999 tentang Badan Informasi dan Komunikasi Nasional sebagaimana telah diubah dengan Keputusan Presiden Republik Indonesia Nomor 7 Tahun 2000 tanggal 19 Januari 2000 tentang Perubahan Atas Keputusan Presiden Republik Indonesia Nomor 153 Tahun 1999 tentang Badan Informasi dan Komunikasi Nasional.

Keputusan Presiden Republik Indonesia Nomor 20 Tahun 2006 tanggal 11 November 2006 tentang Dewan Teknologi Informasi dan Komunikasi Nasional.

Keputusan Ketua Mahkamah Agung Republik Indonesia Nomor 144/KMA/SK/VIII/2007 tanggal 28 Agustus 2007 tentang Keterbukaan Informasi Di Pengadilan.

Keputusan Ketua Komisi Informasi Pusat Republik Indonesia Nomor 02/Kep/KIP/X/2009 tanggal 23 Oktober 2009 tentang Pedoman Pelaksanaan Seleksi dan Penetapan Anggota Komisi Informasi Provinsi dan Komisi Informasi Kabupaten/Kota.

Peraturan Komisi Informasi Nomor 1 Tahun 2010 tanggal 30 April 2010 tentang Standar Layanan Informasi Publik. 